\title{
Penggunaan Bungkil Kelapa Fermentasi Dengan Trichoderma Harzianum Dalam Ransum Untuk Performa Broiler
}

\section{The Use of Fermented Coconut Meal with Trichoderma Harzianum in Rations for Broiler Performance}

\author{
Yona Chintya Salma', Maisuranti ${ }^{1}$ \\ ${ }^{1}$ Program Studi Peternakan, Politeknik Pertanian Negeri Payakumbuh \\ Jl. Raya Negara Km. 7 Tanjung Pati, 26271, Payakumbuh \\ yonachintya55@gmail.com
}

\begin{abstract}
Diterima : 02 Desember 2018
Disetujui : 03 Desember 2018

Diterbitkan : 05 Desember 2018
\end{abstract}

\begin{abstract}
Abstrak: Biaya pakan di peternakan ayam broiler adalah komponen terbesar, sehingga peternak harus dapat memanfaatkan nilai gizi dan kualitas bahan, seperti bungkil kelapa. Bungkil kelapa memiliki 22,41\% protein dan serat kasar 15,15\%, setelah fermentasi, protein meningkat menjadi 35,27\% dan serat kasar lebih rendah menjadi $10,24 \%$. Tujuan penelitian ini adalah memberikan campuran dalam ransum sebagai pakan fermentasi dengan Trichoderma harzianum. Kegiatan penelitian dilakukan dalam dua periode. Periode pertama bulan September 2016 - Oktober 2016, periode kedua November 2016 - Desember 2016 yang diselenggarakan di kandang ayam ras UPT Politeknik Pertanian Negeri Payakumbuh. Alat-alat yang digunakan dalam pemeliharaan ayam pedaging adalah: kabel, bola lampu, isolasi, tirai plastik, timbangan, spayer tangan, tali, ember, baskom, kompor. Bahan yang digunakan adalah DOC, bungkil kelapa fermentasi, ransum komersial, vaksin ND, plastik, kertas koran, rodalon, sekam padi dan kapur. Penggunaan bungkil kelapa yang difermentasi dapat meningkatkan berat badan ayam pedaging. Konsumsi, konversi pakan, penambahan berat badan perlakuan lebih baik daripada kontrol.
\end{abstract}

Kata Kunci : Bungkil Kelapa Fermentasi; Broiler; Performa.

Abstract: Broiler is one source of animal protein needed by the people of Indonesia, Because The price is are relatively affordable and relatively faster growth. The cost of feed in broiler farming is the largest component, so that the farmer should be able to take advantage of the availability of feed ingredients there is no ignoring the nutritional value and quality contained in feed ingredients, such as coconut oilcake. Coconut oilcake had $22.41 \%$ protein and crude fiber $15.15 \%$, after fermentation increased to $35.27 \%$ protein and lower crude fiber becomes $10.24 \%$. The purpose of this research is to know the broiler performance with the use of coconut meal fermented with Trichoderma harzianum as feed mixture in the ration. Research activities carried out in the two periods. The first period dated 22 September 2016 - October 20, 2016, the second period 8 November 2016 - December 6, 2016 which was held in broiler cage UPT Farm Agricultural Polytechnic State of Payakumbuh. The tools used in the maintenance of broiler is: cables, light bulbs, insulation, plastic blinds, light socket lamps, scales, hand spayer, rope, bucket, bailer, basin, cooker, steamer. Materials used are DOC, fermented coconut cake, a commercial ration, ND vaccines, plastics, newsprint, rodalon, rice husks and lime. The use of fermented coconut cake in the feed can increase body weight gain of broilers for coconut cake fermentation has high protein. Consumption, feed conversion, weight gain is better than the control treatment.

Keywords : Fermented Coconut Meal, Broiler, Performance.

\section{Pendahuluan}

Broiler merupakan salah satu sumber protein hewani yang dibutuhkan masyarakat Indonesia, dan merupakan permintaan unggas tertinggi dibandingkan unggas lain, karena harganya relatif terjangkau dan pertumbuhan broiler relatif lebih cepat dengan siklus hidup yang lebih singkat dibanding dengan ternak penghasil daging lainnya, yaitu bisa dipanen dalam waktu satu bulan dibandingkan unggas lainnya, dan perputaran modal pun lebih cepat. Dalam peternakan broiler, terpadu kemampuan peternak dalam sebuah bisnis, kemampuan dalam mengelola dan pemahaman akan teknis dalam beternak secara imbang dan selaras. Sehingga untuk menjadikan sebuah usaha peternakan yang sukses, kita harus memperhatikan berbagai unsur, seperti teknis produksi, manajemen pemeliharaan, dan pemasaran produk itu sendiri. 
Biaya pakan dalam usaha budidaya broiler merupakan komponen terbesar. Salah satu upaya peternak untuk menghasilkan pakan unggas dengan harga yang terjangkau dan untuk menekan biaya produksi, maka penggunaan pakan unggas harus efisien, sehingga peternak harus mampu memanfaatkan ketersediaan bahan pakan yang ada tanpa mengabaikan nilai gizi dan kualitas yang terdapat dalam bahan pakan tersebut, pemilihan bahan pakan yang tepat sebagai campuran maupun tambahan dalam pakan sangat berperan penting dalam produktifitas daging broiler yang akan dihasilkan. Pemanfaatan limbah industri sebagai salah satu contoh bahan pengganti pakan ternak misalnya bungkil kelapa.

Bungkil kelapa merupakan hasil ikutan dari industri pengolahan minyak kelapa yang memiliki warna kecoklatan. Ketersediaan bungkil kelapa tidaklah susah untuk dicari dan bisa dimanfaatkan sebagai pakan ternak, selain itu kebutuhan bungkil kelapa juga tidak bersaing dengan kebutuhan manusia, bungkil kelapa bisa didapatkan di poultry shop. Meskipun bungkil kelapa sudah umum digunakan sebagai bahan pengganti ransum unggas,, akan tetapi pemanfaatannya belum optimal. Hal ini disebabkan tingginya kandungan serat kasar dalam bungkil kelapa sehingga menjadi faktor pembatas untuk ternak unggas, selain itu kelemahan dari bungkil kelapa ini yaitu tingginya kandungan serat kasar namun serat kasar ini dapat diturunkan melalui teknologi fermentasi dengan Trichoderma harzianum yang bisa menghasilkan enzim-enzim perombak selulosa dan hemiselulosa sehingga akan meningkatkan nilai gizi dari bungkil kelapa.

Bungkil kelapa memiliki kandungan lemak yang cukup tinggi mencapai $15 \%$ sehingga mudah rusak, terkontaminasi jamur dan bau tengik. Kelebihan dari bungkil kelapa ini yaitu setelah dilakukan fermentasi proteinnya akan meningkat dari $22,41 \%$ menjadi $35,27 \%$ dan menurunkan serat kasar dari $15,15 \%$ menjadi $10,24 \%$ [1].

Fermentasi merupakan salah satu teknologi pengolahan bahan makanan secara biologis yang melibatkan aktivitas mikroorganisme guna memperbaiki gizi bahan yang berkualitas rendah, serta berfungsi dalam pengawetan bahan dan merupakan suatu cara untuk menghilangkan zat anti nutrisi atau racun yang terkandung dalam suatu bahan makanan [2]. Trichoderma harzianum dapat meningkatkan perombakan bahan-bahan organik, disamping itu juga akan melonggarkan dan memutuskan ikatan lignin dan selulosa serta memfermentasikannya tanpa menimbulkan pengaruh yang merugikan, yang diakibatkan oleh bahan-bahan organik yang tidak terurai.

Berdasarkan hal tersebut maka penulis tertarik untuk melakukan penelitian dengan judul "penggunaan bungkil kelapa fermentasi dengan
Trichoderma harzianum dalam ransum untuk performa broiler".

Tujuan penelitian yaitu untuk mengetahui performa broiler dengan pemanfaatan bungkil kelapa hasil fermentasi Trichoderma harzianum sebagai bahan pakan dalam ransum broiler.

\section{Materi dan Metode}

\subsection{Waktu dan tempat pelaksanaan}

Kegiatan Penelitian ini dilaksanakan selama 3 bulan, yaitu pada bulan September sampai bulan Desember 2016 di Farm Politeknik Pertanian Negeri Payakumbuh.

\subsection{Alat dan bahan}

Alat-alat yang digunakan selama penelitian ini adalah bola lampu, tempat pakan, tempat minum, sekop, ember, handsprayer, sapu lidi, kabel, kuas, peting lampu, kompor, baskom, dandang dan inkubator.

Bahan-bahan yang dipakai terdiri dari DOC, ransum komersil, bungkil kelapa, Trichoderma harzianum, mineral, sekam padi, vaksin ND, desinfektan, gula, koran, tirai plastik dan tali rafia.

\subsection{Metode pelaksanaan}

Data diperoleh dari data primer dan sekunder. Data primer berdasarkan hasil pengamatan di lapangan dengan cara mengikuti secara aktif kegiatan yang berhubungan langsung dengan pemeliharaan ayam.

\subsection{Parameter}

Parameter yang diukur adalah :

1. Pertambahan bobot badan (PBB);

2. Konsumsi (g/ekor/hari);

3. Konversi;

4. Mortalitas.

\subsection{Pelaksanaan penelitian}

\subsubsection{Persiapan kandang}

Sebelum kandang digunakan, terlebih dahulu dilakukan sanitasi kandang dan perlengkapan kandang seperti lantai, sekat, tempat pakan, serta tempat minum. Tahap pembersihan kandang yang pertama yaitu dengan cara membersihkan kotoran yang menempel di dalam kandang seperti lantai dan dinding dengan cara menyapu, menyiram dan menyikat sampai bersih, kemudian seluruh bagian kandang disemprot menggunakan rodalon dengan dosis $2 \mathrm{ml} /$ liter air yang bertujuan untuk membunuh kuman dan bakteri, proses ini dinamakan dengan desinfeksi. Setelah desinfeksi dilakukan pengapuran, pengapuran dilakukan dengan cara pencampuran kapur dengan air secukupnya, dan tidak terlalu cair/encer lalu dioleskan pada permukaan kandang dengan menggunakan kuas, yang bertujuan untuk menghambat pertumbuhan bakteri yang masih 
tersisa disela-sela sudut kandang yang sulit terjangkau.

Tempat pakan dan minum dicuci bersih dengan menggunakan deterjen dan air mengalir yang bertujuan untuk menghilangkan bakteri dan kotoran yang melekat.

Sekat dipasang sesuai dengan banyak DOC yang dipelihara, dan dibersihkan terlebih dahulu. Sekat ini berfungsi untuk membatasi luas kandang, sehingga DOC tidak bebas berpencar, sekat dibagi menjadi dua kelompok, yaitu satu untuk perlakuan dan satu untuk kontrol. Sekat dipasang sesuai dengan jumlah DOC yang akan dipelihara, ketentuannya untuk $1 \mathrm{~m} 2$ dapat menampung 50 ekor DOC [3].

Litter atau alas kandang menggunakan sekam padi yang diberikan dengan ketinggian sekitar 5-7 cm dan kemudian dilapisi dengan kertas koran yang bertujuan agar anak ayam lebih cepat mengenal pakan dan tidak memakan bahan litter. Alas koran sebagai pelapis litter ini digunakan hingga anak ayam berumur 3 atau 4 hari [4]. Pembalikan litter dilakukan setiap hari mulai hari ke 8, Pembalikan litter bertujuan untuk mencegah agar litter tidak menggumpal, dan litter dibuang pada saat broiler berumur 15 hari.

Kondisi alas litter yang basah akan menyebabkan terjadinya pembentukan gas beracun seperti amoniak yang dapat meningkatkan risiko penyakit, menurunkan sistem kekebalan, mengganggu pertumbuhan, dan menimbulkan penyakit saluran pernapasan [5].

Kandang dilengkapi dengan 2 buah bola lampu listrik dengan masing-masing 75 watt untuk 100 ekor ayam yang berfungsi sebagai pemanas dan penerangan terutama pada malam hari. Pemasangan lampu dengan cara digantung dengan ketinggian 15 $30 \mathrm{~cm}$ dari lantai atau disesuaikan agar suhu merata di dalam kandang. Untuk menentukan suhu sesuai dengan kebutuhan, bisa dilihat melalui penyebaran anak ayam didalam brooder.

Selain kegiatan di atas, kandang juga dilengkapi dengan tirai plastik yang dipasang sekeliling kandang untuk menghambat hembusan angin kencang serta masuknya percikan air hujan ke dalam kandang. Kandang ditutup rapat dengan tirai hingga ayam berumur satu minggu karena saat ini ayam sangat peka terhadap keadaan lingkungan. Pada minggu ke 2 tirai plastik tersebut sudah dapat dibuka 1/3 bagian, pada minggu berikutnya tirai dibuka seluruhnya hingga sampai masa panen [6].

\subsubsection{Persiapan ransum}

Ransum yang dipersiapkan untuk perlakuan yaitu ransum komersil dengan campuran 5\% bungkil kelapa fermentasi dari total ransum pada umur 3 hari sampai panen seperti pada gambar 1. Sedangkan untuk kontrol diberikan $100 \%$ ransum komersil sampai panen. Pemberian ransum dilakukan secara adlibitum.

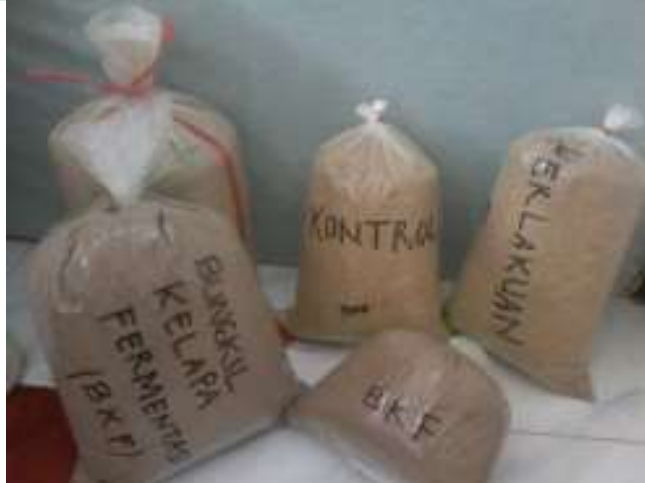

Gambar 1. Pakan yang digunakan

\subsubsection{Persiapan bibit}

DOC dipesan dari Poultry Shop dan langsung diantar ke kandang. Berat awal 50 gr/ekor, memiliki postur tubuh yang seragam, sehat dan lincah, kaki kuat dan mengkilat seperti berminyak, tidak terdapat cacat, mata cerah dan bersinar, bulu bersih dan mengkilap, tidak ada feses yang melekat pada bagian kloaka. Saat DOC datang 1-2 jam sebelumnya suhu indukan harus diatur sesuai dengan kebutuhan DOC, begitu juga dengan tempat pakan dan minumnya sudah harus tersedia dalam indukan. Air gula dengan dosis 20-50 gr/litter disediakan sebagai sumber energi, karena DOC yang baru datang biasanya stress dan kekurangan energi setelah perjalanan panjang dari Hatchery. Pada waktu penerimaan bibit dilakukan penimbangan, dan untuk seterusnya dilakukan dengan jangka waktu sekali dalam seminggu.

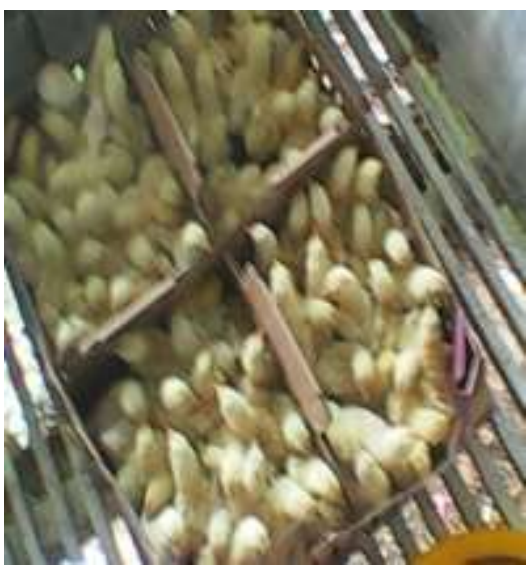

Gambar 2. Bibit yang digunakan

\subsubsection{Manajemen pemeliharaan}

Pemberian pakan dilakukan secara bersamaan waktunya dengan pemberian air gula, pada hari pertama pemberian pakan dilakukan dengan cara menaburkan pakan diatas litter koran dan ditempat pakan. Hal ini tujuannya untuk mempercepat DOC mengenal pakan.

Pakan diberikan minimal 2 kali sehari pada pagi hari jam 07.00-07.30 WIB dan sore hari jam 16.3017.30 WIB. Standar pemberian pakan yaitu 160 
gr/ekor/minggu pada minggu pertama, minggu kedua $383 \mathrm{gr} / \mathrm{ekor} / \mathrm{minggu}$, minggu ketiga 614 gr/ekor/minggu, minggu ke empat 864 gr/ekor/minggu [7].

Broiler sangat rentan terhadap penyakit, maka diperlukan manajemen pencegahan dan pengendalian penyakit yang baik. Pencegahan agar ayam tidak terserang penyakit, harus melakukan sanitasi secara berkala, seperti menjaga kebersihan indukan dan kandang serta lingkungan di sekitarnya setiap hari dan melakukan desinfeksi minimal 1 kali seminggu. Selain itu, melakukan vaksin ND pada umur 4 hari. Karena penyakit ND sering menyerang
DOC pada minggu-minggu awal atau pada fase starter.

Dalam Penelitian ini, pemeliharaan dilaksanakan selama 2 periode. Jumlah tiap periode yaitu sebanyak 100 ekor yang terdiri dari 50 ekor untuk perlakuan dan 50 ekor untuk kontrol. Pemeliharaan dilaksanakan selama 28 hari.

\section{Hasil dan Pembahasan}

Dari hasil pelaksanaan Penelitian didapatkan pertambahan bobot badan, konsumsi ransum, dan konversi ransum seperti tertera dalam Tabel 1.

Tabel 1. Data performa broiler.

\begin{tabular}{|c|c|c|c|c|c|}
\hline \multirow{2}{*}{ No } & \multirow{2}{*}{ uraian } & \multicolumn{2}{|c|}{ Periode 1} & \multicolumn{2}{|c|}{ Periode 2} \\
\hline & & Kontrol & Perlakuan & Kontrol & Perlakuan \\
\hline 1 & PBB (g/ekor/hari) & 46,107 & 46,678 & 48,75 & 51,464 \\
\hline 2 & Konsumsi (g/ekor/hari) & 78,134 & 72,847 & 83,418 & 73,248 \\
\hline 3 & Konversi & 1,694 & 1,560 & 1,571 & 1,423 \\
\hline 4 & Mortalitas & $14 \%$ & $8 \%$ & $12 \%$ & $2 \%$ \\
\hline
\end{tabular}

\subsection{Pertambahan bobot badan}

Pemeliharaan broiler dengan penggunaan bungkil kelapa fermentasi dalam pakan sebanyak $5 \%$ dari total pakan menghasilkan pertumbuhan bobot badan yang lebih tinggi antara perlakuan dari pada kontrol, dimana pada perlakuan didapatkan 46,678 g/ekor/hari pada periode pertama dan 51,464 g/ekor/hari pada periode kedua, apabila dibandingkan dengan kontrol yaitu 46,107 g/ekor/hari pada periode pertama dan 48,75 g/ekor/hari pada periode kedua, dimana pertambahan bobot badan pemeliharaan periode kedua lebih tinggi dari pada periode pertama. Pertambahan bobot badan broiler selama penelitian juga lebih tinggi jika dibandingkan dengan penelitian yang dilakukan oleh [1] yang memperoleh pertambahan bobot badan 38,890 g/ekor/hari pada perlakuan dan 38,623 g/ekor/hari pada kontrol.

Pemberian pakan dengan bungkil kelapa fermentasi sebanyak 5\% dari total ransum kepada broiler bisa meningkatkan PBB karena tingginya protein yang dimiliki oleh bungkil kelapa fermentasi, jika bungkil kelapa fermentasi dan komersil dicampur ke pakan ternak proteinnya mencapai 23,50\%, sedangkan untuk pakan kontrol proteinnya hanya berkisar antara $19-22 \%$. Hal ini sesuai dengan pernyataan bahwa salah satu yang mempengaruhi besar kecilnya pertambahan bobot badan ayam pedaging adalah konsumsi pakan dan terpenuhinya kebutuhan zat makanan [9].

\subsection{Konsumsi ransum}

Konsumsi ransum perlakuan pada periode pertama yaitu 72,847 g/ekor/hari dan untuk periode kedua 73,248 g/ekor/hari, sedangkan kontrol pada periode pertama 78,134 g/ekor/hari dan periode kedua 83,418 g/ekor/hari. Konsumsi pada perlakuan lebih rendah dibandingkan kontrol dan konsumsi pada periode pertama lebih tinggi dari konsumsi ransum periode kedua. Besar ayam dan tahap produksi menyebabkan perbedaan konsumsi [10].

Palatabilitas merupakan faktor yang menentukan tingkat konsumsi ransum pada ternak, sedangkan palatabilitas dipengaruhi oleh bentuk, bau, rasa, tekstur, dan suhu makanan yang diberikan, karena bau bungkil kelapa yang tengik dan yang berbentuk tepung makanya konsumsi pakan perlakuan lebih rendah dari pada konsumsi pakan kontrol selama penelitian, dimana unggas lebih menyukai ransum berbentuk butiran dari pada tepung [11], karena bungkil kelapa fermentasi memiliki protein yang tinggi maka dihasilkan pertambahan bobot badan yang tinggi meskipun dengan konsumsi pakan yang rendah.

\subsection{Konversi ransum}

Konversi ransum adalah jumlah pakan yang dihabiskan broiler untuk menghasilkan satu kilogram bobot badan. Konversi ransum yang baik yaitu konversi yang menujukkan angka yang rendah artinya konsumsi ransum lebih efisien.

Pada periode pertama konversi ransum perlakuan 1,560 dan 1,432 pada periode kedua, sedangkan untuk kontrol 1,694 periode pertama dan 1,571 pada periode kedua. Jika dibandingkan konversi ransum perlakuan lebih rendah dari pada kontrol dan konversi ransum pada periode pertama lebih tinggi dari periode kedua. Jadi dapat disimpulkan bahwa selama kegiatan penelitian ini ransum perlakuan lebih efisien dari pada ransum kontrol.

Pemberian bungkil kelapa fermentasi dalam pakan ternak sebagai subsitusi mampu menghemat pakan selama pemeliharaan penelitian, karena harga 
bungkil kelapa fermentasi lebih murah dari harga pakan per kg, akan tetapi pemberian bungkil kelapa fermentasi mempunyai batasan, dan pemberian yang terlalu banyak bisa menurunkan performa broiler.

\subsection{Mortalitas}

Tingginya mortalitas broiler selama pemeliharaan diduga karena manajemen pemeliharaan dan lingkungan yang kurang bagus seperti adanya kebisingan sehingga menyebabkan ayam menjadi stress dan sakit. Hal ini sesuai dengan pernyataan [12] kematian ayam broiler selama pemeliharaan lebih banyak disebabkan oleh penyakit.

\section{Kesimpulan}

Berdasarkan hasil dan pembahasan dapat disimpulkan:

(1). Pertambahan bobot badan broiler pada perlakuan mendekati kontrol, dimana pada periode pertama pertambahan bobot badan untuk perlakuan adalah 46,68 g/ekor/hari dan 51,46 g/ekor/hari pada periode kedua, sedangkan pada kontrol periode pertama 46,11 $\mathrm{g} /$ ekor/hari dan 48,75 g/ekor/hari untuk periode kedua.

(2). Konsumsi pakan pada kontrol mendekati pada perlakuan. Konsumsi pakan perlakuan periode pertama 72,85 g/ekor/hari dan 73,25 g/ekor/hari pada periode kedua, sedangkan pada kontrol $78,13 \mathrm{~g} / \mathrm{ekor} / \mathrm{hari}$ periode pertama dan 83,42 g/ekor/hari pada periode kedua.

(3). Konversi ransum broiler pada perlakuan mendekati dengan kontrol. Konversi ransum perlakuan periode pertama adalah 1,56o dan periode kedua 1,423 dan untuk kontrol konversi periode pertama adalah 1,694 dan periode kedua 1,571 .

\section{Daftar Pustaka}

[1] Mairizal dan E. Erwan. 2006. Respon biologis pemberian bungkil kelapa hasil fermentasi dengan Trichoderma harzianum terhadap performans ayam pedaging. Jurnal Fakultas Peternakan Universitas Jambi. Jambi.

[2] Dewi, M., D. Syukriani dan Y. S. Amir. 2016. BKPM Teknologi pengolahan pakan. Politeknik pertanian negeri payakumbuh.Tanjung pati. 1-2 Hal.

[3] Zumrotun. 2012. Manajemen Brooding Pada Ayam Broiler. Artikel, Berita Dinas.

[4] Tamalluddin, F. 2014. Panduan Lengkap Ayam Broiler. Penebar Swadaya. Jakarta.

[5] Nuroso. 2009. Panen Ayam Pedaging dengan Produksi 2 x Lipat. Penebar Swadaya. Jakarta.

[6] Rasyaf, M. 2009. Panduan Beternak Ayam Pedaging. Penebar Swadaya. Jakarta.
[7] Ciomas Adisatwa. 2016. Standar performance broiler. Recording file. (dilihat 7 juli 2016).

[8] Fadilah, R. 2013. Beternak Ayam Broiler. Agro Media Pustaka. Jakarta.

[9] Fadilah, R. 2005. Panduan mengelola peternakan ayam broiler komersil. PT. Agro Media. Pustaka. Jakarta.

[10] Wahju, J. 2004. Ilmu Nutrisi Unggas. Edisi Ke4. Universitas Gadjah Mada Press, Yogyakarta.

[11] Nastiti, R. 2014. Menjadi Milyarder Budidaya Ayam Broiler. Pustaka baru press. Yogyakarta.

[12] Amrullah, I.K. 2003. Nutrisi Ayam Broiler. Lembaga Satu Gunung Budi. Bogor. 